\title{
Prevalence and diversity of Salmonella enterica in water, fish and lettuce in Ouagadougou, Burkina Faso
}

\author{
Oumar Traoré ${ }^{1,2,3^{*}}$, Outi Nyholm³ ${ }^{3}$ Anja Siitonen ${ }^{3}$, Isidore Juste O Bonkoungou², Alfred S Traoré ${ }^{1}$, Nicolas Barro ${ }^{1}$ \\ and Kaisa Haukka ${ }^{3,4}$
}

\begin{abstract}
Background: This study investigated the prevalence, serotypes and antimicrobial sensitivity patterns of Salmonella enterica in environment in Ouagadougou, Burkina Faso. A total of 476 samples, consisting of 36 samples of tap water, 51 samples of well water, 87 samples of channel water, 44 samples of reservoir water, 238 samples of fish, and 20 samples of lettuce were examined using standard bacteriological procedures for Salmonella.

Results: Salmonella were isolated from 98 samples. Salmonella were rare in drinking water, since they were not found at all from the tap water, and only in $2 \%$ of well water. Salmonella were more common in the water of reservoir of Tanghin (15\%), reservoir of Yamtenga (20\%), and in the water channels in the city (from 20 to $31 \%$ ). Salmonella were commonly isolated from the fish (24\%) caught from the reservoir of Tanghin and from the lettuce (50\%) irrigated with water from Tanghin. The Salmonella isolates were found to represent 50 different serotypes. The 11 most common serotypes were Salmonella Bredeney and S. Colindale (both 8.2 \%), S. Muenster (6.1 \%), S. Korlebu (5.1 \%), S. Eastbourne and S. Poona (both $4.1 \%$ ), and S. Agona, S. Derby, S. Drac, S. Senftenberg, S. Waycross (each $3.1 \%$ ), accounting for $51.3 \%$ of all the isolates. In general, the Salmonella strains were sensitive to the antimicrobials tested, but two strains were resistant to streptomycin and many more intermediate to streptomycin or sulphonamide.
\end{abstract}

Conclusion: This study highlights the common prevalence of Salmonella and the high diversity of Salmonella serotypes in aquatic environment in Ouagadougou, Burkina Faso. Therefore, various human activities linked to water and consumption of water-related products, such as fish and lettuce, can lead to human Salmonella infections.

Keywords: Salmonella, Serotypes, Water, Fish, Lettuce, Antimicrobials

\section{Background}

Microbiologically contaminated water is a potential source of human enteric infections and indicates poor maintenance of hygiene-related infrastructure and problems in implementation of control measures especially in developing countries. Discharge of inadequately treated sewage, run-off

\footnotetext{
* Correspondence: marrou4@yahoo.fr

'Laboratoire de Biologie Moléculaire d'Epidémiologie et de Surveillance des bactéries et virus transmis par les aliments, CRSBAN/Département de Biochimie-Microbiologie, UFR SVT-Université de Ouagadougou, 03 B.P. 7021 , Ouagadougou 03, Burkina Faso

2Laboratoire National de Santé Publique, 09 B.P. 24, Ouagadougou 09, Burkina Faso

Full list of author information is available at the end of the article
}

storm water and leakage of animal waste into the environment can lead to deterioration of quality of water sources. Salmonella has been found to survive in tropical fresh waters, such as rivers, streams and wells in Sierra Leone, for several days [1]. Salmonella carried by fish and other aquaculture products as well as by fresh produce irrigated with dirty water has been indicated as a vehicle for a growing number of enteric disease outbreaks [2-6]. Use of feces-contaminated water to irrigate the produce has been reported to lead contaminating of soil and vegetables with Salmonella for an extended period of time [7, 8].

Salmonella enterica remains an important cause of diarrhoeal illness in humans and Salmonella infections
C Biomed Central

(C) 2015 Traoré et al. This is an Open Access article distributed under the terms of the Creative Commons Attribution License (http://creativecommons.org/licenses/by/4.0), which permits unrestricted use, distribution, and reproduction in any medium, provided the original work is properly credited. The Creative Commons Public Domain Dedication waiver (http:// creativecommons.org/publicdomain/zero/1.0/) applies to the data made available in this article, unless otherwise stated. 
are a major health concern that continue to have a serious economic impact worldwide [9, 10]. Furthermore, specifically in sub-Saharan Africa, non-typhoidal Salmonella is among the leading causes of bacterial bloodstream infections in adults and children [11-13]. Yet, the common sources of Salmonella infections in Africa are poorly known.

In our previous study in Ouagadougou in Burkina Faso, $9 \%$ of the children suffering from diarrhea were found to be infected by Salmonella [14]. In order to find out the potentially important sources for the Salmonella infections, we examined the frequency and diversity of Salmonella in beef, mutton and poultry carcasses $[15,16]$ as well as in the feces of cattle, poultry, swine and hedgehogs [17]. In the present study we expand our studies on the potential Salmonella sources to include water, fish and irrigated lettuce.

In Ouagadougou, channels built to drain runoff rain water are used as a human biological waste deposit by people living close to them. Even a major hospital disposes much of its waste into a channel running nearby, casting serious doubt on the hygienic quality of the water. Elsewhere in Africa similar open storm drainage channels have been found to expose people to infections by Salmonella and other pathogens [18]. The channels in Ouagadougou run into reservoirs, which are nowadays used for fishing activities, irrigation of vegetables, washing clothes and cars. Furthermore, the reservoirs remain a contingency source of drinking water during dry season being intermittently part of municipal infrastructure. In this study, we examined water samples from two reservoirs, two channels as well as from wells and treated tap water system for possible Salmonella contamination. Furthermore, we examined fish caught from one of the reservoirs and lettuce irrigated with its water. Specifically, the aims of this study were (1) to determine the prevalence of Salmonella, (2) to assess Salmonella serotypes and antimicrobial resistance profiles of the obtained isolates and (3) to compare the serotypes to those previously obtained from the local children, animals and retail meat.

\section{Results}

Salmonella enterica was isolated from 98 (20,6\%) of the total of 476 samples examined (Table 1). From all of the drinking water samples (taps and wells) only one isolate was obtained. Instead, in the channel, reservoir and fish samples Salmonella was common, $15-31 \%$ of the samples were positive (Table 1). In the lettuce samples the frequency was the highest, since half of them were positive.

The obtained 98 Salmonella enterica isolates represented 50 different serotypes, all the sample types containing a variety of serotypes (Table 1 ). The most frequent serotypes were Salmonella Colindale and $S$. Bredeney (8 isolates
Table 1 Prevalence of Salmonella and different serotypes detected

\begin{tabular}{|c|c|c|c|c|}
\hline \multicolumn{2}{|l|}{ Sample types } & \multirow{2}{*}{$\begin{array}{l}\text { Examined } \\
36\end{array}$} & \multirow{2}{*}{$\begin{array}{l}\text { Positive (\%) } \\
0\end{array}$} & \multirow{2}{*}{$\begin{array}{l}\text { Number of serotypes } \\
0\end{array}$} \\
\hline Tap water & & & & \\
\hline Well water & & 51 & $1(2 \%)$ & 1 \\
\hline \multirow[t]{2}{*}{ Channel water } & $C A$ & 52 & 16 (31 \%) & 13 \\
\hline & $C B$ & 35 & 7 (20 \%) & 7 \\
\hline \multirow[t]{2}{*}{ Reservoir water } & RY & 10 & $2(20 \%)$ & 2 \\
\hline & RT & 34 & $5(15 \%)$ & 4 \\
\hline Fish & & 238 & 57 (24 \%) & 34 \\
\hline Salad & & 20 & 10 (50 \%) & 4 \\
\hline Total & & 476 & 98 (21\%) & 50 \\
\hline
\end{tabular}

$\mathrm{CA}=$ Channel $\mathrm{A}, \mathrm{CB}=$ Channel $\mathrm{B}, \mathrm{RY}=$ Reservoir of Yamtenga $\mathrm{RT}=$ Reservoir of Tanghin

each) (Table 2). Salmonella Colindale was isolated from lettuce as well as from the reservoirs and channels, whereas another common serotype in lettuce, $S$. Korlebu, was not detected in the water samples. S. Bredeney was common in fish but was also detected in water and lettuce samples (Table 2). S. Bredeney, S. Give, S. Colindale, $S$. Eastbourne, $S$. Schwarzengrund, $S$. Poona and $S$. Llandoff were isolated from fish and water samples, but only $S$. Colindale and $S$. Schwarzengrund were isolated from both fish and the reservoir of Tanghin where they were caught from. No common serotypes were found from the two different reservoirs. Only two serotypes, $S$. Colindale and $S$. Senftenberg were common to the two different channels.

Almost all of the isolates were sensitive to the 12 antimicrobials tested. Only two isolates, $S$. Wagadugu and $S$. Adabraka isolated from the water of the reservoir of Yamtenga, were resistant to streptomycin. However, 27 of all the 98 isolates showed decreased sensitivity (i.e. were intermediate) to streptomycin and 5 to sulphonamide.

\section{Discussion}

Our investigation on prevalence of Salmonella enterica in water from taps, wells, channels and reservoirs, fish, and lettuce grown in Ouagadougou, Burkina Faso, indicated that Salmonella contamination is rare in drinking water but common in the samples from the other sources (15-50\% prevalence). In a previous study in Lagos, Nigeria, Salmonella were isolated from 18,5 \% of drinking water samples [19]. Serotyping of the Salmonella isolated in our study revealed the great diversity of serotypes in these sources: we identified 50 different serotypes among the 98 isolates. Recently, in Burkina Faso, 383 Salmonella strains were isolated from animal faeces (cattle, poultry, swine and hedgehogs), representing 81 different serotypes [17]. Of those, Agona, Bredeney, Brive, Carmel, Chester, Colindale, Derby, Drac, Eastbourne, Fresno, Galiema, Kokomlemle, Korlebu, Muenster, Nima, Nottingham, Poona, Rissen, Schwarzenground, 
Table 2 Diversity of Salmonella serotypes

\begin{tabular}{|c|c|c|c|c|c|c|c|c|c|}
\hline \multirow[t]{4}{*}{ Serotypes } & \multicolumn{8}{|l|}{ Origins } & \multirow[t]{4}{*}{ Total $(n=476$} \\
\hline & \multicolumn{6}{|l|}{ Water } & \multirow[t]{3}{*}{ Fish $(n=238)$} & \multirow[t]{3}{*}{ Lettuce $(n=20)$} & \\
\hline & \multirow[t]{2}{*}{$\operatorname{Tap}(n=36)$} & \multirow[t]{2}{*}{ Well $(n=51)$} & \multicolumn{2}{|c|}{ Channel $(n=87)$} & \multicolumn{2}{|c|}{ Reservoirs $(n=44)$} & & & \\
\hline & & & $\mathrm{CA}(n=52)$ & $\mathrm{CB}(n=35)$ & $\mathrm{RY}(n=10)$ & $\mathrm{RT}(n=34)$ & & & \\
\hline S. Adabraka & 0 & 0 & 0 & 0 & 1 & 0 & 0 & 0 & $1(1 \%)$ \\
\hline S. Agona & 0 & 0 & 0 & 0 & 0 & 0 & 3 & 0 & $3(3 \%)$ \\
\hline S.Bredeney & 0 & 0 & 1 & 0 & 0 & 0 & 6 & 1 & 8 (8.2 \%) \\
\hline S. Brive & 0 & 0 & 0 & 0 & 0 & 0 & 1 & 0 & $1(1 \%)$ \\
\hline S. Brochum & 0 & 0 & 0 & 0 & 0 & 0 & 2 & 0 & $2(2 \%)$ \\
\hline S. Carmel & 0 & 0 & 0 & 0 & 0 & 1 & 0 & 0 & $1(1 \%)$ \\
\hline S. Chester & 0 & 0 & 1 & 0 & 0 & 0 & 0 & 0 & $1(1 \%)$ \\
\hline S. Colindale & 0 & 0 & 1 & 1 & 0 & 2 & 0 & 4 & $8(8.2 \%)$ \\
\hline S. Cubana & 0 & 0 & 0 & 0 & 0 & 0 & 1 & 0 & $1(1 \%)$ \\
\hline S. Derby & 0 & 0 & 0 & 0 & 0 & 0 & 3 & 0 & $3(3.1 \%)$ \\
\hline S.Drac & 0 & 0 & 0 & 0 & 0 & 0 & 3 & 0 & $3(3.1 \%)$ \\
\hline S. Ealing & 0 & 0 & 0 & 0 & 0 & 0 & 1 & 0 & $1(1 \%)$ \\
\hline S. Eastbourne & 0 & 0 & 3 & 0 & 0 & 0 & 1 & 0 & $4(4.1 \%)$ \\
\hline S. Eastglam & 0 & 0 & 0 & 0 & 0 & 0 & 2 & 0 & $2(2 \%)$ \\
\hline S. Elisabethwille & 0 & 0 & 0 & 0 & 0 & 0 & 1 & 0 & $1(1 \%)$ \\
\hline S. Freshno & 0 & 0 & 0 & 0 & 0 & 0 & 1 & 0 & $1(1 \%)$ \\
\hline S. Galiema & 0 & 0 & 0 & 1 & 0 & 0 & 0 & 0 & $1(1 \%)$ \\
\hline S. Gerland & 0 & 0 & 0 & 0 & 0 & 0 & 0 & 1 & $1(1 \%)$ \\
\hline S. Give & 0 & 0 & 0 & 1 & 0 & 0 & 1 & 0 & $2(2 \%)$ \\
\hline S. Havana & 0 & 0 & 0 & 0 & 0 & 0 & 2 & 0 & $2(2 \%)$ \\
\hline S. Hermannsweder & 0 & 0 & 0 & 0 & 0 & 0 & 1 & 0 & $1(1 \%)$ \\
\hline S. Kentucky & 0 & 0 & 0 & 0 & 0 & 0 & 1 & 0 & $1(1 \%)$ \\
\hline S. Kokomlemle & 0 & 0 & 0 & 0 & 0 & 0 & 1 & 0 & $1(1 \%)$ \\
\hline S.Korlebu & 0 & 0 & 0 & 0 & 0 & 0 & 1 & 4 & 5 (5.1\%) \\
\hline S. Llandoff & 0 & 0 & 1 & 0 & 0 & 0 & 1 & 0 & $2(2 \%)$ \\
\hline S. Mentevideo & 0 & 0 & 0 & 0 & 0 & 0 & 1 & 0 & $1(1 \%)$ \\
\hline S. Mbandaka & 0 & 0 & 0 & 0 & 0 & 0 & 1 & 0 & $1(1 \%)$ \\
\hline S.Minnesota & 0 & 0 & 0 & 0 & 0 & 0 & 1 & 0 & $1(1 \%)$ \\
\hline S. Muenster & 0 & 0 & 0 & 0 & 0 & 0 & 6 & 0 & $6(6.1 \%)$ \\
\hline S. Nima & 0 & 0 & 0 & 0 & 0 & 0 & 1 & 0 & $1(1 \%)$ \\
\hline S. Nottingham & 0 & 0 & 0 & 0 & 0 & 0 & 2 & 0 & $2(2 \%)$ \\
\hline S. Offa & 0 & 0 & 0 & 0 & 0 & 0 & 1 & 0 & $1(1 \%)$ \\
\hline S.Ouagadougou & 0 & 0 & 1 & 0 & 0 & 0 & 0 & 0 & $1(1 \%)$ \\
\hline S. Poona & 0 & 1 & 0 & 1 & 0 & 0 & 2 & 0 & $4(4.1 \%)$ \\
\hline S. Rissen & 0 & 0 & 0 & 1 & 0 & 0 & 0 & 0 & $1(1 \%)$ \\
\hline S. Schwazengrund & 0 & 0 & 0 & 0 & 0 & 1 & 1 & 0 & $2(2 \%)$ \\
\hline S.Senftenberg & 0 & 0 & 2 & 1 & 0 & 0 & 0 & 0 & $3(3.1 \%)$ \\
\hline S. Shubra & 0 & 0 & 1 & 0 & 0 & 0 & 0 & 0 & $1(1 \%)$ \\
\hline S. Teshie & 0 & 0 & 1 & 0 & 0 & 0 & 0 & 0 & $1(1 \%)$ \\
\hline S. Tilene & 0 & 0 & 1 & 0 & 0 & 0 & 1 & 0 & $1(1 \%)$ \\
\hline S. Typhimirium & 0 & 0 & 0 & 0 & 0 & 0 & 1 & 0 & $1(1 \%)$ \\
\hline
\end{tabular}


Table 2 Diversity of Salmonella serotypes (Continued)

\begin{tabular}{|c|c|c|c|c|c|c|c|c|c|}
\hline S. Virchow & 0 & 0 & 1 & 0 & 0 & 0 & 0 & 0 & $1(1 \%)$ \\
\hline S. Waedenswil & 0 & 0 & 0 & 0 & 0 & 0 & 1 & 0 & $1(1 \%)$ \\
\hline S. Wagadugu & 0 & 0 & 0 & 1 & 1 & 0 & 0 & 0 & $2(2 \%)$ \\
\hline S. Waycross & 0 & 0 & 0 & 0 & 0 & 0 & 3 & 0 & $3(3.1 \%)$ \\
\hline S. Group A & 0 & 0 & 0 & 0 & 0 & 0 & 1 & 0 & $1(1 \%)$ \\
\hline S.GroupB:4,12,27:z35:I,w & 0 & 0 & 0 & 0 & 0 & 0 & 1 & 0 & $1(1 \%)$ \\
\hline S.GroupE1,3,19;r:- & 0 & 0 & 1 & 0 & 0 & 0 & 0 & 0 & $1(1 \%)$ \\
\hline S.GroupG13,22:Z:- & 0 & 0 & 0 & 0 & 0 & 1 & 0 & 0 & $1(1 \%)$ \\
\hline S. Group 0:53 & 0 & 0 & 1 & 0 & 0 & 0 & 0 & 0 & 1 (1\%) \\
\hline Total & 0 & 1 & 16 & 7 & 2 & 5 & 57 & 10 & 98 \\
\hline
\end{tabular}

$\mathrm{CA}=$ Channel $\mathrm{A}, \mathrm{CB}=$ Channel $\mathrm{B}, \mathrm{RY}=$ Reservoir of Yamtenga $\mathrm{RT}=$ Reservoir of Tanghin

Senftenberg, Typhimurium and Virchow were isolated also in our study indicating a possible transfer between animals, their faeces, water, fish and irrigated vegetables. The previously most commonly reported serotypes in Africa (Cameroon, Mali, Marocco, Senegal and Tunisia), Enteritidis and Anatum [20], were not isolated in our study. Serotypes Muenster (the second most common serotype isolated from fish), Cubana, Kentucky, Montevideo, Poona, Fresno, Virchow and Typhimurium detected in our study, were also isolated in stool specimens from children under 5 years old suffering from acute diarrhea in Ouagadougou and in rural Burkina Faso $[14,21]$.

Salmonella were isolated from $23 \%$ of the surface water samples (channels and reservoirs). This frequency is lower than in the survey conducted in Yaoundé, Cameroon, where Salmonella were isolated in $49.4 \%$ of the surface water samples [22]. We isolated 22 different serotypes from surface water, showing more diversity in Salmonella than reported elsewhere [23-26]. No same serotypes were found from the two reservoirs studied, which may be due to their different external factors. The reservoir of Tanghin located in the city is influenced by people and the reservoir of Yamtenga in the rural area is less frequented by people but more by animals. In any case, the presence of Salmonella in the surface waters reveals the health risk posed by the use of this water for irrigation. It has been indicated that the potential hazards may be associated with poor hygienic standard of waters influenced by human sewage, livestock farming, or industry [27]. S. Poona, the only Salmonella serotype we isolated from well water, was also isolated from children under 5 years suffering from acute diarrhoea in Ouagadougou and in rural Burkina Faso [14, 21].

Among the fish samples examined, 57 (24\%) were positive to Salmonella with high diversity of serotypes, 34 different ones were detected. In Kenya, along the Lake Victoria Beaches, almost 17 \% of Tilapia samples were positive for Salmonella with four different serotypes [28]. In Indonesia, about $10 \%$ of fresh fish were reported to be contaminated by Salmonella [5]. The high prevalence of Salmonella in fish in Ouagadougou is not surprising since they were caught from water of poor hygienic quality. S. Schwarzengrund and Colindale were the serotypes found in both the fish and the reservoir of Tanghin. Although as many as 34 different Salmonella serotypes were detected in the fish from Tanghin, only four serotypes were detected in its water, presumably because the salmonellas are more sparsely distributed in the water environment and thus in water samples. $S$. Typhimurium, an important clinical serotype, was isolated only from one fish sample $(0,4 \%)$ in our study, thus, being much rarer than in the study of fish along the Lake Victoria Beaches, where it was more isolated (8 \%) [28]. In another study, conducted in Winam Gulf of Lake Victoria, Kenya, S. Typhimurium was isolated from $6 \%$ of fish harvested [29]. We did not find any $S$. Typhi, perhaps because the enrichment technique used is not optimal to this serotype [30].

Our results revealed that $50 \%$ of the analysed lettuce samples were positive for Salmonella with four different serotypes ( $S$. Bredeney, $S$. Colindale, $S$. Gerland and $S$. Korlebu).

$S$. Colindale was found in lettuce, reservoir water of Tanghin and the channels. This suggested that the lettuce has been contaminated by irrigating water. On the other hand, $S$. Korlebu and $S$. Gerland found in lettuce samples were not detected in the water sources, but $S$. Korlebu has instead been identified in cattle faeces in Ouagadougou [17].Bacteria in lettuce might also come from another origin e.g. manure used as a fertilizer. Salmonella has been demonstrated to contaminate vegetables (carrots, radish, lettuce and parsley) in field experiments following treatment with contaminated manure compost or irrigation water [7, 31]. In Finland, iceberg lettuce contaminated with $S$. Reading and Newport caused a nationwide outbreak, according to a traceback investigation [32]. $S$. Colindale which was common in our lettuce samples was also described as the most common serotype in Gambia of 
non-typhoidal Salmonella in cases of enteric infection under the age of 5 years [10].

Reassuringly, our results showed that the great majority of environmental Salmonella strains are susceptible to the antimicrobials tested. Two strains, $S$. Wagadugu and $S$. Adabraka, both isolated from the reservoir water of Yamtenga were resistant to streptomycin. Domestic animals treated by antibiotics might transfer resistant Salmonella from their faeces to this reservoir leading to antimicrobial resistance. No resistant Salmonella were detected in fish reflecting the fact that antimicrobial agents are not used in fish farming in Burkina Faso. On the contrary, $52(14 \%)$ of the Salmonella isolates from animal faeces in Ouagadougou were resistant to one or more tested antimicrobials [17]. In Nigeria, emerging multidrug-resistant Salmonella serotypes were commonly found from water sources [19].

\section{Conclusion}

Our study highlights the common presence of Salmonella in samples from different aquatic environments and indicates potential sources of human Salmonella infections. We detected a high diversity of serotypes among the strains, which were, however, mainly fully sensitive for the common antimicrobials. But nearly $30 \%$ of the isolates were intermediate, which gives rise to concern. These results indicate a need for microbiological quality monitoring of the fish production and water, which is used in various human activities eg. in irrigation of fresh vegetables.

\section{Methods}

\section{Sampling}

The first sampling period was from October 2008 to February 2009 (corresponding to the dry season) in different parts of Ouagadougou and Yamtenga out of the town. The samples included 36 water samples from 4 taps (9 samples from each tap), 51 samples from 3 wells (17 samples from each well), 11 samples from a channel (Channel A), water of which flows directly to the reservoir of Tanghin, 21 samples from a channel, which runs past a hospital (Channel B) and close to the reservoir of Tanghin (during the rainy season the waters of Channel $B$ and the reservoir overflow to each other), 9 samples from the reservoir of Tanghin and 10 samples from the reservoir of Yamtenga, which is not influenced by channel water. Water from wells and taps were collected as the users did, by lifting with a bucket from the well or taking directly from the tap. Water samples from the reservoir and the channel were taken with a disinfected ladle fixed to a long stick [33]. The samples were transported to the laboratory on ice and analyzed within two hours after collection.

The second sampling period was from March to August 2010 in Ouagadougou. The period from March to May is part of dry season, and the period from June to August part of rainy season. The samples included 25 water samples from the reservoir of Tanghin, 41 from Channel A, 14 from Channel B and 238 fish (tilapia, Oreochromis niloticus) from the reservoir of Tanghin. The fish were an average length of $12 \mathrm{~cm}$, purchased alive from local fishermen and processed in the laboratory within four hours after collection. The outer surface of the killed fish was disinfected by wiping with $70 \%$ ethyl alcohol for two minutes, followed by three washings with sterile water. The intestine was removed aseptically by using a scalpel and ground with a sterile mortar and pestle [33]. Lettuce grown in one garden using irrigation water from the reservoir of Tanghin was also sampled. Ten samples consisting of inner leaves of lettuce were placed in sterile plastic bags, kept in an icebox and processed in a laboratory the same day.

\section{Microbiological analyses}

Broth enrichment technique was used to enhance detection of Salmonella strains $1 \mathrm{~g}$ of each crushed fish intestine was added to $9 \mathrm{ml}$ of buffered peptone water (BPW, Liofilchem, Italy) and $25 \mathrm{~g}$ of lettuce was weighed and added to $225 \mathrm{ml}$ of BPW, stomached and incubated at $37{ }^{\circ} \mathrm{C}$ for $18-20 \mathrm{~h}$. From drinking water samples (taps and wells), one litre was filtered through the membrane with $0,45 \mu \mathrm{m}$ pore size and the membrane was transferred into $90 \mathrm{ml}$ of buffered peptone water (BPW). Reservoir and channel waters were so turbid that $10 \mathrm{ml}$ of water sample was directly added to $90 \mathrm{ml}$ of BPW and incubated at $37^{\circ} \mathrm{C}$ overnight. Next day, $0.1 \mathrm{ml}$ from each BPW broth was added to $10 \mathrm{ml}$ of Rappaport-Vassiliadis broth (Oxoid, England) and incubated at $42{ }^{\circ} \mathrm{C}$ for $24 \mathrm{~h}$. A loop-full of enriched broth was streaked onto the XLD agar (Oxoid, Basingstoke, England) and incubated at $37^{\circ} \mathrm{C}$ for $24 \mathrm{~h}$. Identity of the colonies with black centre was confirmed biochemically using urea, indole, ONPG, Kligler Hajna (Liofilchem, Italy), lysine decarboxylase, citrate and mannitol tests. API 20E strips (BioMérieux, Marcy l'Etoile, France) were used for further confirmation.

The isolates were conserved in heart infusion broth with $15 \%$ of glycerol in the freezer and sent to the Bacteriology Unit the National Institute for Health and Welfare (THL) in Finland for serotyping according to the KaufmannWhite scheme [34]. All isolates were also tested for susceptibility to 12 different antimicrobial agents using the disk diffusion method on Mueller Hinton II agar (Oxoid, England) following the EUCAST guidelines (http:// www.eucast.org). E. coli ATCC 25922 was used as a control. The antimicrobial disks (Oxoid) used were nalidixic acid $(30 \mu \mathrm{g})$, ciprofloxacin $(5 \mu \mathrm{g})$, ampicillin $(10 \mu \mathrm{g})$, cefotaxime $(5 \mu \mathrm{g})$, imipenem $(10 \mu \mathrm{g})$, tetracycline $(30 \mu \mathrm{g})$, gentamicin $(10 \mu \mathrm{g})$, chloramphenicol $(30 \mu \mathrm{g})$, streptomycin $(10 \mu \mathrm{g})$, sulphonamide $(300 \mu \mathrm{g})$, mecillinam $(10 \mu \mathrm{g})$ and trimethoprim $(5 \mu \mathrm{g})$. 


\section{Competing interests}

None of the authors have any competing financial or other interests that could influence or bias the contents of this paper.

\section{Authors' contributions}

OT carried out the sampling and strains isolation, serotyping and their antibiotics susceptibility and drafted the manuscript, IJOB, AST and NB supervised the sampling and strains isolation, ON, AS and $\mathrm{KH}$ supervised the strains serotyping and antibiotics susceptibility and participated in writing the manuscript. All authors read and approved the final version of the manuscript.

\section{Acknowledgments}

This study was funded by the Academy of Finland grant 122600 to collaboration between the Finnish National Institute for Health and Welfare (THL) and CRSBAN/University of Ouagadougou and by the International Foundation for Science (IFS) grant to OT. The authors thank personnel of the Bacteriology Unit at THL for the technical advice and practical help.

\section{Author details \\ ${ }^{1}$ Laboratoire de Biologie Moléculaire d'Epidémiologie et de Surveillance des bactéries et virus transmis par les aliments, CRSBAN/Département de Biochimie-Microbiologie, UFR SVT-Université de Ouagadougou, 03 B.P. 7021, Ouagadougou 03, Burkina Faso. 'Laboratoire National de Santé Publique, 09 B.P. 24, Ouagadougou 09, Burkina Faso. ${ }^{3}$ Bacteriology Unit, Department of Infectious Disease Surveillance and Control, National Institute for Health and Welfare (THL), P.O. Box 30, FI-00271 Helsinki, Finland. ${ }^{4}$ Department of Food and Environmental Sciences, University of Helsinki, P.O. Box 56, FI-00014 Helsinki, Finland.}

\section{Received: 29 January 2015 Accepted: 13 July 2015 Published online: 31 July 2015}

\section{References}

1. Wright R. The survival patterns of selected faecal bacteria in tropical fresh waters. Epidemiol Infect. 1989;103:603-11.

2. Lynch MF, Tauxe RV, Hedberg CW. The growing burden of foodborne outbreaks due to contaminated fresh produce: risks and opportunities. Epidemiol Infect. 2009;137:307-15.

3. Amagliani G, Brandi G, Schiavano GF. Incidence and role of Salmonella in seafood safety. Food Res Int. 2012;45:780-8.

4. Jacobsen CS, Bech TB. Soil survival of Salmonella and transfer to freshwater and fresh produce. Food Res Int. 2012;45:557-66

5. Kusumaningrum HD, Suliantari, Dewanti-Hariyadi R. Multidrug resistance among different serotypes of Salmonella isolates from fresh products in Indonesia. Inter Food Research J. 2012;19:57-63.

6. Olgunoglu IA: Salmonella in Fish and Fishery Products, Salmonella - A Dangerous Foodborne Pathogen. Dr. Barakat S M Mahmoud (Ed.), 2012. ISBN: 978-953-307-782-6, InTech, Available from: http://www.intechopen.com/books/ salmonella-a-dangerous-foodborne-pathogen/salmonella-in-fish-and-fisheryproducts.

7. Islam M, Morgan J, Doyle MP, Phatak SC, Millner P, Jang X. Fate of Salomella enterica serovar Typhimurium on carrots and radishes grown in fields treated with contaminated manure composts or irrigation water. Appl Environ Microbiol. 2004;70:2497-502.

8. Ongeng D, Muyanja C, Geeraerd AH, Springael D, Ryckeboer J. Survival of Escherichia coli 0157:H7 and Salmonella enterica serovar Typhimurium in manure and manure-amended soil under tropical climatic conditions in Sub-Saharan Africa. J Appl Microbiol. 2011;110:1007-22.

9. Majowicz SE, Musto J, Scallan E, Angulo FJ, Kirk M, O'Brien SJ, et al. The Global Burden of Nontyphoidal Salmonella Gastroenteritis. Clin Infect Dis. 2010;50:882-9.

10. Dione MM, Ikumapayi UN, Saha D, Mohammed NI, Geerts S, Leven N, et al. Clonal differences between non-typhoidal Salmonella (NTS) recovered from children and animals living in close contact in the Gambia. PloS Negl Trop Dis. 2011:5:1148.

11. Reddy EA, Shaw AV, Crump JA. Community-acquired bloodstream infections in Africa: a systemic review and meta-analysis. Lancet Infect Dis. 2010;10:417-32.

12. Dione MM, Ikumapayi N, Saha D, Mohammed NI, Adegbola RA, Geerts S, et al. Antimirobial Resistance and virulence genes of non-typhoidal
Salmonella isolates in the Gambia and Senegal. J Infect Dev Ctries. 2011:5:765-75

13. Feasy NA, Dougan G, Kingsley RA, Heyderman RS, Gordon M. Invasive non-typhoidal salmonella disease: an emerging and neglected tropical disease in Africa. Lancet. 2012;379:2489-99.

14. Bonkoungou IJO, Haukka K, Österblad M, Hakanen A, Traoré AS, Barro N et al. Bacterial and viral etiology of childhood diarrhea in Ouagadougou, Burkina Faso. BMC Pediatr. 2013;13.

15. Kagambèga A, Haukka K, Siitonen A, Traoré AS, Barro N. Prevalence of Salmonella enterica and the hygienic indicator Escherichia coli in raw meat at markets in Ouagadougou, Burkina Faso. J Food Protect. 2011;74:1547-51.

16. Kagambèga A, Barro N, Traoré AS, Siitonen A, Haukka K. Characterization of Salmonella enterica and detection of the virulence genes specific to diarrheagenic Escherichia coli from poultry carcasses in Ouagadougou, Burkina Faso. Foodborne pathog dis. 2012;9:1-5.

17. Kagambèga A, Lienemann $T$, Aulu L, Traoré AS, Barro N, Siitonen A, et al. Prevalence and characterization of Salmonella enterica from the feces of cattle, poultry, swine and hedgehogs in Burkina Faso and their comparison to human Salmonella isolates. BMC Microbiol. 2013;13:253.

18. Katukiza AY, Ronteltap M, van der Steen P, Foppen JWA, Lens PNL. Quantification of microbial risks to human health caused by waterborne viruses and bacteria in an urban slum. J Appl Microbiol. 2013;116:447-63.

19. Akinyemi KO, Iwalokun BA, Foli F, Oshodi K, Coker AO. Prevalence of multiple drug resistance and screening of enterotoxin (stn) gene in Salmonella enterica serovars from water sources in Lagos, Nigeria. Public Health. 2011:125:65-71.

20. Galanis E, Danilo MA, Wong LF, Patrick ME, Binsztein N, Cieslik A, et al. Web-based Surveillance and Global Salmonella Distribution, 2000-2002. Emerg Infect Dis. 2006;12:381-7.

21. Dembélé R, Konaté A, Bonkoungou IJO, Kagambèga A, Konaté K, Bagré TS, et al. Serotyping and antimicrobial susceptibility of Salmonella isolated from children under five years of age with diarrhea in rural Burkina Faso. Afr J Microbiol Res. 2014;8:3157-63.

22. Ateba BH, Nougang ME, Noah EO, Tamatcho KB, Tawedi RE, Mbilongo $J$, et al. Occurrence of Salmonella spp in surface waters of Yaoundé, Cameroon. J Environ Sci Water Resource. 2012;1:243-50.

23. Catalao Dionisio LP, Joao M, Ferreiro VS, Fidalgo ML, García Rosado ME, Borrego JJ. Occurrence of Salmonella spp. in estuarine and coastal waters of Portugal. Antonie van Leeuwenhoek. 2000;78:99-66.

24. Martinez-Urtaza J, Saco M, de Novoa J, Perez-Pineiro P, Peiteado J, Lozano-Leon A, et al. Influence of environmental factors and human activity on the presence of Salmonella serovars in a marine environment. Appl Environ Microbiol. 2004;70:2089-97.

25. Haley BJ, Cole DJ, Lipp EK. Distribution, diversity, and seasonality of waterborne Salmonellae in a rural watershed. Appl Environ Microbiol. 2009; 75:1248-55.

26. Gorski L, Parker CT, Liang A, Cooley MB, Jay-Russell MT, Gordus AG, et al. Prevalence, distribution, and diversity of Salmonella enterica in a major produce region of California. Appl Environ Microbiol. 2011;77:2734-48.

27. Martinez-Urtaza J, Liebana E. Use of pulsed-field gel electrophoresis to characterize the genetic diversity and clonal persistence of Salmonella senftenberg in mussel processing facilities. Int J Food Microbiol. 2005; 105:153-63.

28. Awuor WS, Miruka OD, Eliud WN. Characterisation of Salmonella Isolated from Nile Tilapia (Oreochromis niloticus) along Lake Victoria Beaches in Western Kenya. Inter J Biol Med Sciences. 2011;1:51-6.

29. Onyango MD, Wandili S, Kakai R, Waindi ED. Isolation of Salmonella and Shigella from fish harvested from the Winam Gulf of Lake Victoria, Kenya. J Infect Dev Ctries. 2009;3:99-104.

30. Hammack TS, Jacobson AP, Andrews WH. The effect of preenrichment and selective enrichment media on recovery of Salmonella Typhi from the tropical fruit mamey. J AOAC Int. 2008;91:83-91.

31. Islam M, Morgan J, Doyle MP, Phatak SC, Millner P, Jang X. Persistence of Salmonella enterica serovar Typhimurium on lettuce and parsley and in soils on which they were grown in fields treated with contaminated water. Foodborne Pathog Dis. 2004;1:27-35.

32. Lienemann T, Niskanen T, Guedes S, Siitonen A, Kuusi M, Rimhanen-Finne R. Iceberg lettuce as suggested source of a nationwide outbreak caused by two Salmonella serotypes, Newport and Reading, in Finland in 2008. J Food Prot. 2011;6:1035-40. 
33. Traoré O, Martikainen O, Siitonen A, Traoré AS, Barro N, Haukka K.

Occurrence of Vibrio cholerae in fish and water from a reservoir and a neighbouring channel in Ouagadougou/ Burkina Faso. J Infect Dev Ctries. 2014;8:1334-8.

34. Kauffmann F. Classification and nomenclature of the genus Salmonella. Acta Pathol Microbiol Scand [B] Microbiol Immunol. 1971;79:421-2.

Submit your next manuscript to BioMed Central and take full advantage of:

- Convenient online submission

- Thorough peer review

- No space constraints or color figure charges

- Immediate publication on acceptance

- Inclusion in PubMed, CAS, Scopus and Google Scholar

- Research which is freely available for redistribution 